\title{
ANALISIS PERBANDINGAN KINERJA BERDASARKAN CAMELS PADA BANK YANG TERDAFTAR DI OTORITAS JASA KEUANGAN
}

\author{
IWAN PELEALU1) HERMAN KARAMOY2) AGUS TONY POPUTRA ${ }^{3)}$
}

Program Studi Magister Akuntansi Fakultas Ekonomi dan bisnis Universitas Sam Ratulangi

E-mail : iwanpelealu@yahoo.com

\begin{abstract}
Bank's financial health can be defined as an ability of the bank in conducting its banking operations as normal and can meet its obligations properly in ways that conform with applicable laws and regulations. Rules about bank's financial helath that applied in Indonesia cover various apsects of the bank activities, ranging from fund rasing until the use and disbursement of the fund. Assesment of the banks includes an assessment of the factors of capital, asset quality, management, earnings, liquidity, and sensitivity of market known as CAMELS. Financial Services Authority of Indonesia has classified all convensional and commercial banks in Indonesia to State Banks, Regional Banks, Private Banks, Mixed Banks, and Foreign Banks.

This study is aimed to comparative analysis based on CAMELS in State Banks, Regional Banks, Private Banks, Mixed Banks, and Foreign Banks. The population in this study is all convensional banks (State Banks, Regional Banks, Private Banks, Mixed Banks, and Foreign Banks) listed in Financial Services Authority of Indonesia from 2010-2015 consists of 105 banks. Respondents were chosen by using purposive sampling and the number of samples the criteria is 20 banks (with details 4 State Banks, 4 Regional Banks, 4 Private Banks, 4 Mixed Banks, and 4 Foreign Banks). The analytical method used in this study is the average difference ( $t$-test).

The result shows that the usage of proxy CAMELS ratio to analyze comparioson of bank performance found that State Banks are the best among those Regional Banks, Private Banks, Mixed Banks, and Foreign Banks.
\end{abstract}

Key Words: financial statements, CAMELS, core capital, common equity tier 1 , risk profile, bank's financial health, Basel, Financial Services Authority of Indonesia.

\begin{abstract}
Abstrak. Tingkat kesehatan bank dapat diartikan sebagai kemampuan suatu bank melakukan kegiatan operasional perbankan secara normal dan mampu memenuhi semua kewajibannya dengan baik dengan cara-cara yang sesuai dengan peraturan perundangan yang berlaku. Aturan mengenai kesehatan bank yang diterapkan di Indonesia mencakup berbagai aspek dalam kegiatan bank, mulai dari penghimpunan dana sampai dengan penggunaan dan penyaluran dana. Penilaian tingkat kesehatan bank mencakup penilaian terhadap faktor-faktor permodalan, kualitas aset, manajemen, rentabilitas, likuiditas, dan senstivitas pasar dikenal dengan CAMELS (Capital Ratio, Asset Quality Ratio, Management, Earning, Liquidity, and Sensitivity of Market). Pihak Otoritas Jasa Keuangan membagi klafisikasi seluruh Bank yang berada di Indonesia kedalam 5 kategori/kelompok yaitu: Bank Nasional, Bank Pembangunan Daerah, Bank Swasta Nasional, Bank Campuran, dan Bank Asing.

Tujuan yang hendak dicapai dalam penelitian ini adalah untuk menganalisis perbandingan kinerja berdasarkan CAMELS pada Bank Nasional dengan Bank Pembangunan Daerah, Bank Nasional dengan Bank Swasta Nasional, dan Bank Campuran dengan Bank Asing.

Populasi dalam penelitian ini adalah seluruh bank (Bank Nasional, Bank Pembangunan Daerah, Bank Swasta Nasional, Bank Campuran, dan Bank Asing) yang tercatat di Otoritas Jasa Keuangan tahun 2010-2015 sebanyak 153 bank, dengan menggunakan purposive sampling jumlah sampel yang memenuhi kriteria adalah sebanyak 20 bank (dengan perincian 4 bank nasional, 4 bank pembangunan daerah, 4 bank swasta nasional, 4 bank campuran, dan 4 bank asing). Metode analisis yang digunakan adalah uji beda rata-rata (t-test).

Hasil penelitian diperoleh menunjukkan bahwa kinerja bank nasional adalah yang paling baik dibandingkan bank pembangunan daerah, bank swasta nasional, bank campuran, dan bank asing.

Kata Kunci: laporan keuangan bank, CAMELS, modal inti, modal inti utama, profil risiko, tingkat kesehatan bank, Basel, Otoritas Jasa Keuangan.
\end{abstract}




\section{Pendahuluan}

Bank is a financial intermediary that accepts deposits and lend money to the people and an institution providing the service of transferring money and generating income (Kaur, Kaur, \& Singh, 2015).Kesehatan bank dapat diartikan sebagai kemampuan suatu bank melakukan kegiatan operasional perbankan secara normal dan mampu memenuhi semua kewajibannya dengan baik dengan cara-cara yang sesuai dengan peraturan perundangan yang berlaku. Permasalahan dalam dunia perbankan saat ini adalah mengatur posisi rasio CAMELS pada tingkat ideal. Dimana perbankan dituntut untuk melakukan hal-hal sebagai berikut.

1. Menjaga rasio kecukupan modal minimum agar tidak berada dibawah batas profil risiko beserta buffer yang dipersyaratkan oleh otoritas yang berwenang, sehingga bank dapat leluasa bergerak dalam menjalankan aktivitasnya.

2. Menjaga likuiditas yang ada termasuk menjaga kepercayaan masyarakat terhadap pemerintah lewat sektor perbankan.

3. Menjaga kestabilan moneter lewat membantu Bank Indonesia mengendalikan jumlah uang beredar di masyarakat yang didalamnya pengendalian suku bunga.

4. Mendukung berbagai program pemerintah, termasuk didalamnya pengentasan kemiskinan lewat pemberikan kredit kepada usaha mikro kecil menengah (UMKM) dengan suku bunga yang relatif rendah.

5. Disamping itu menjaga agar profitabilitas dapat tumbuh dengan maksimal sehingga memberikan deviden yang maksimal kepada para pemegang saham.

Ditambah dengan profil, struktur, budaya, dan pangsa pasar dari masing-masing bank yang beraneka ragam, maka peneliti mengambil kesimpulan bahwa CAMELS memegang peran penting sebagai alat ukur dalam mengukur tingkat kesehatan bank, dan secara makro merupakan indikator pengukuran kinerja pemerintah dalam mengatur dan menjaga stabilitas moneter. Atas permasalahan tersebut, peneliti merasa tertarik untuk melakukan analisa perbandingan kinerja terhadap industri perbankan.

Bank Indonesia membuat kategori risiko terdiri dari risiko kredit, risiko pasar, risiko operasional, risiko likuiditas, risiko kepatuhan, risiko strategis, risiko reputasi, dan risiko hukum.

Pada dasarnya penilaian tingkat kesehatan bank merupakan penilaian terhadap hasil usaha bank dalam waktu tertentu dan tingkat kesehatan bank akan digolongkan dalam lima peringkat komposit masing-masing faktor.

Menurut POJK No. 4/POJK.03/2016 Tentang Penilaian Tingkat Kesehatan Bank Umum, Bank dengan kategori Peringkat Komposit 1 adalah mencerminkan kondisi Bank yang secara umum sangat sehat sehingga dinilai sangat mampu menghadapi pengaruh negatif yang signifikan dari perubahan kondisi bisnis dan faktor eksternal lainnya tercermin dari peringkat faktor-faktor penilaian, antara lain profil risiko, penerapan GCG, rentabilitas, dan permodalan yang secara umum sangat baik. Apabila terdapat kelemahan maka secara umum kelemahan tersebut tidak signifikan.

Bank dengan kategori Peringkat Komposit 2 adalah mencerminkan kondisi Bank yang secara umum sehat sehingga dinilai mampu menghadapi pengaruh negatif yang signifikan dari perubahan kondisi bisnis dan faktor eksternal lainnya, tercermin dari peringkat faktor-faktor penilaian, antara lain profil risiko, penerapan GCG, rentabilitas, dan permodalan yang secara umum baik. Apabila terdapat kelemahan maka secara umum kelemahan tersebut kurang signifikan.

Bank dengan kategori Peringkat Komposit $\mathbf{3}$ adalah mencerminkan kondisi yang secara umum cukup sehat sehingga dinilai cukup mampu menghadapi pengaruh negatif yang signifikan dari perubahan kondisi bisnis dan faktor eksternal lainnya, tercermin dari peringkat faktor-faktor penilaian, antara lain profil risiko, penerapan GCG, rentabilitas, dan permodalan, yang secara umum cukup baik. Apabila terdapat kelemahan maka secara umum kelemahan 
tersebut cukup signifikan dan apabila tidak berhasil diatasi dengan baik oleh manajemen dapat mengganggu kelangsungan usaha Bank.

Bank dengan kategori Peringkat Komposit 4 adalah mencerminkan kondisi yang secara umum kurang sehat sehingga dinilai kurang mampu menghadapi pengaruh negatif yang signifikan dari perubahan kondisi bisnis dan faktor eksternal lainnya, tercermin dari peringkat faktor-faktor penilaian, antara lain profil risiko, penerapan GCG, rentabilitas, dan permodalan, yang secara umum kurang baik. Terdapat kelemahan yang secara umum signifikan dan tidak dapat diatasi dengan baik oleh manajemen serta mengganggu kelangsungan usaha Bank.

Bank dengan kategori Peringkat Komposit $\mathbf{5}$ adalah mencerminkan kondisi yang secara umum tidak sehat sehingga dinilai tidak mampu menghadapi pengaruh negatif yang signifikan dari perubahan kondisi bisnis dan faktor eksternal lainnya, tercermin dari peringkat faktorfaktorpenilaian, antara lain profil risiko, penerapan GCG, rentabilitas, dan permodalan, yang secara umum tidak baik. Terdapat kelemahan yang secara umum sangat signifikan sehingga untuk mengatasinya dibutuhkan dukungan dana dari pemegang saham atau sumber dana dari pihak lain untuk memperkuat kondisi keuangan Bank.

Untuk kedelapan risiko tersebut dapat ditentukan apa risiko yang perlu mendapatkan prioritas perhatian manajemen untuk dikelola dengan baik, karena dipandang berpotensi merugikan bank. Dalam menilai profil risiko bank wajib pula memperhatikan cakupan penerapan manajemen risiko sebagaimana diatur dalam POJK No. 18/POJK.03/2016 tentang Penerapan Manajemen Risiko Bank Umum dan SE BI No. 13/24/DPNP tentang Penilaian Tingkat Kesehatan Bank Umum.

CAMEL (Capital Ratio, Asset Quality Ratio, Management, Earning, and Liquidity) merupakan alat ukur yang lazim dipergunakan oleh setiap industri perbankan.

On January $1^{\text {st }} 1997$, a sixth component " $\mathrm{S}$ " (sensitivity to market risk), was included in CAMEL rating systems. Researchers have argued that the CAMEL(S) can help evaluate the financial conditons of a bank, its management quality and its compliance with regulators. That is, the ratios can be used as an effective tool to identify a bank's problems. (Nurazi \& Evans, 2005).

Rasio keuangan bank didasarkan pada SE No.13/30/DPNP Tanggal 16 Desember 2011 Perihal Perubahan Ketiga atas Surat Edaran Bank Indonesia Nomor 3/30/DPNP tanggal 14 Desember 2001 perihal Laporan Keuangan Publikasi Triwulanan dan Bulanan Bank Umum serta Laporan Tertentu yang Disampaikan kepada Bank Indonesia. Dari SE NO. 13/30/DPNP Tanggal 16 Desember 2011 tersebut telah mengalami beberapa penyempurnaan, terutama yang berkaitan dengan komponen perhitungan Kewajiban Penyediaan Modal Minimum yang selalu disesuaikan dengan regulasi terbaru.

\section{CAPITAL}

Capital adequacy is the capital expected to maintain balance with the risks exposure of the financial institution such as credit risk, market risk and operational risk, in order to absorb the potential losses and protect the financial institution's debt holder. "Meeting statutory minimum capital requirement is the key factor in deciding the capital adequacy, and maintaining an adequate level of capital is a critical element. (Sandhya, 2014)

Capital is important for a bank to maintain depositors' confidence and preventing the bank from going bankrupt. It reflects the overall financial condition of banks and also the ability of management to meet the need of additional capital (Suba \& Jogi, 2015)

Otoritas Jasa Keuangan sangat memperhatikan rasio Kewajiban Penyediaan Modal Minimum atau KPMM dari setiap bank, karena rasio Kewajiban Penyediaan Modal Minimum merupakan organ yang paling vital dari setiap bank. Perhitungan KPMM yang terbaru telah diadopsi oleh Otoritas Jasa Keuangan yang dikenal dengan nama Basel III untuk menggantikan 
Basel II yang sebelumnya juga telah diadopsi oleh Bank Indonesia. KPMM merupakan rasio permodalan yang menunjukkan kemampuan bank dalam rangka pengembangan usaha dan menyerap kemungkinan risiko kerugian yang diakibatkan kegiatan operasional bank.

Sedangkan aktiva tertimbang menurut risiko (risk weighted asset) tersebut mencakup aktiva dalam neraca/laporan posisi keuangan dan beberapa pos dalam rekening administratif (laporan komitmen dan kontijensi). Dalam menghitung ATMR, terhadap masing-masing pos aktiva diberikan bobot risiko yang besarnya didasarkan pada kadar risiko yang terkandung pada aktiva itu sendiri atau bobot risiko yang didasarkan pada golongan dan portofolio nasabah, penjamin serta jenis dan sifat agunan yang apabila eligible akan menjadi faktor pengurang dari risiko. Perhitungan ATMR dibagi atas 3 risiko, yaitu ATMR Risiko Kredit, ATMR Risiko Pasar, dan ATMR Risiko Operasional.

Perhitungan ATMR Risiko Kredit diatur oleh Otoritas Jasa Keuangan lewat Surat Edaran Otoritas Jasa Keuangan No. 42/SEOJK.03/2016 Tanggal 28 September 2016 Tentang Pedoman Perhitungan Aset Tertimbang Menurut Risiko untuk Risiko Kredit dengan Menggunakan Pendekatan Standar.

Perhitungan ATMR Risiko Operasional diatur oleh Otoritas Jasa Keuangan lewat Surat Edaran Otoritas Jasa Keuangan No. 24/SEOJK.03/2016 Tanggal 14 Juli 2016 Tentang Pedoman Perhitungan Aset Tertimbang Menurut Risiko Untuk Risiko Operasional Dengan Menggunakan Pendekatan Indikator Dasar (PID).

Perhitungan ATMR Risiko Pasar diatur oleh Otoritas Jasa Keuangan lewat Surat Edaran Otoritas Jasa Keuangan No. 38/SEOJK.03/2016 Tanggal 08 September 2016 Tentang Pedoman Penggunaan Metode Standar Dalam Perhitungan Kewajiban Penyediaan Modal Minimum Bank Umum Dengan Memperhitungkan Risiko Pasar.

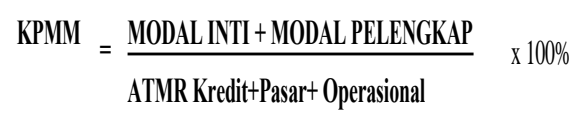

Tambahan modal sebagai penyangga (BUFFER) seperti yang diatur dalam POJK No. 34/POJK.03/2016 adalah sebagai berikut.

1. Capital Conservation Buffer (Modal Konservasi) yaitu cadangan tambahan diatas modal minimum yang dibentuk saat ekonomi booming sebagai buffer disaat periode krisis. Dalam dokumen CP Basel III disebutkan bahwa pemupukan modal konservasi dapat dilakukan melalui pengurangan pembagian keuntungan, seperti pengurangan pembayaran deviden, buy back saham. Dapat pula melakukan penambahan modal melalui sektor swasta. Perlakuan untuk buffer ini pada Bank yang tergolong sebagai Bank Umum Kegiatan Usaha (BUKU) 3 dan BUKU 4. Buffer yang wajib dibentuk adalah 2,5\% dari ATMR dan otoritas yang menetapkan adalah Otoritas Jasa Keuangan.

2. Countercyclical Buffer (Modal Kontersiklikal): adalah Tambahan modal untuk memelihara stabilitas sektor perbankan dari risiko sistemik akibat pertumbuhan pasar yang terlalu besar yang ditandai dengan adanya pertumbuhan kredit perbankan yang berlebihan sehingga berpotensi mengganggu stabilitas sistem keuangan. Perlakuan untuk buffer ini berlaku bagi seluruh Bank. Buffer yang wajib dibentuk adalah 0-2,5\% dari ATMR dan otoritas yang menetapkan adalah Otoritas Jasa Keuangan. Otoritas Jasa Keuangan bisa menetapkan lebih dari kisaran tersebut, sesuai dengan perkembangan kondisi makro ekonomi.

3. Capital Surcharge untuk D-SIB (Domestic Systemically Importance Bank) yaitu tambahan capital yang diperuntukkan mengurangi dampak negative terhadap stabilitas sistem keuangan dan perekonomian apabila terjadi kegagalan dari Kelompok Bank yang mempunyai dampak besar (sistemik) terhadap sistem keuangan dan perekonomian domestic melalui peningkatan kemampuan Bank dalam menyerap kerugian. Dalam dokumen CP Basel III disebutkan bahwa dalam menilai atas risiko sistemik, otoritas pengawas akan melakukan uji 
terhadap pertumbuhan kredit dan indicator lainnya untuk memastikan telah terjadi risiko sistemik. Buffer yang wajib dibentuk adalah 1\% - 2,5\% dari ATMR dan ditetapkan oleh otoritas yang berwenang (mengacu pada ketentuan UU OJK yang mengatur Protokol Koordinasi). Otoritas yang berwenang dapat menetapkan lebih dari kisaran tersebut.

\section{ASET QUALITY}

"Poor asset quality is the major cause of most bank failures". A most important asset category is the loan portfolio; the greatest risk facing the bank is the risk of loan losses derived from the delinquent loans. The credit analyst should carry out the asset quality assessment by performing the credit risk management and evaluating the quality of loan portfolio using trend analysis and peer comparison. Measuring the asset quality is difficult because it is mostly derived from the analyst's subjectivity. (Sandhya, 2014)

Aktiva produktif merupakan sumber pendapatan utama dari kegiatan usaha perbankan. Yang dimaksud dengan aktiva produktif disini sesuai PBI No. 14/15/PBI/2012 tentang Penialian Kualitas Aset Bank Umum adalah penyediaan dana Bank untuk memperoleh penghasilan, dalam bentuk kredit, surat berharga, penempatan dana antar bank, tagihan akseptasi, tagihan atas surat berharga yang dibeli dengan janji dijual kembali (reverse repurchase agreement), tagihan derivatif, penyertaan, transaksi rekening administratif serta bentuk penyediaan dana lainnya yang dapat dipersamakan dengan itu.

Penggunaan dana bank pada aktiva produktif wajib dilaksanakan berdasarkan prinsip kehati-hatian. Pengurus bank harus menjaga kualitas aktiva produktifnya agar selalu dalam keadaan baik. Penilaian kualitas aktiva produktif dilihat dari Cadangan Kerugian Penurunan Nilai terhadap aktiva produktif yang dimiliki bank.

Perhitungan NPL dipisahkan menjadi dua, yaitu NPL Gross dan NPL Nett. Perhitungan NPL Gross diambil dari total kredit bermasalah (kredit yang digolongkan kurang lancar, diragukan, dan macet) dibagi dengan total kredit posisi neraca. Sedangkan NPL Nett diambil dari total kredit bersamalah seteah dikurangi penyisihan CKPN atas kredit bermasalah tersebut dan dibagi dengan total kredit posisi neraca. Secara matematis dapat digambarkan sebagai berikut.

NPL Gross $=\frac{\text { KREDIT BERMASALAH }}{\text { TOTAL KREDIT }} \times 100 \%$

NPL Nett $=\frac{\text { KREDIT BERMASALAH-CKPN }}{\text { TOTAL KREDIT }} \times 100 \%$

\section{MANAGEMENT}

Management is considered to be the single most important element in the CAMEL rating system because it plays a substantial role in a bank's success; however, it is subject to measure as the asset quality examination. (Sandhya, 2014)

Rasio yang digunakan dalam penelitian ini adalah rasio Net Intrest Margin (NIM). Rasio NIM digunakan untuk mengukur kemampuan manajemen bank dalam mengelola aktiva produktifnya untuk menghasilkan pendapatan bunga bersih. Pendapatan bunga bersih diperoleh dari pendapatan bunga dikurangi biaya bunga. Semakin besar rasio ini maka meningkatnya pendapatan bunga atas aktiva produktif yang dikelola bank sehingga kemungkinan suatu bank dalam kondisi bermasalah semakin kecil. (Angel, 2014)

Secara matematis, untuk menghitung NIM adalah sebagai berikut:

$$
\mathrm{NIM}=\frac{\text { PENDAPATAN BUNGA BERSIH }}{\text { RATA-RATA AKTIVA PRODUKTIF }} \quad \mathrm{x} 100 \%
$$




\section{EARNING}

Suatu bank dimasukkan dalam klasifikasi efisien apabila rasio laba terhadap volume usaha mencapai sekurang-kurangnya $1.2 \%$ dan rasio biaya operasional terhadap pendapatan operasional tidak melebihi 93.5\%. (Angel, 2014)

Aspek yang diukur dalam rasio rentabilitas ini yaitu menggunakan Return On Assets (ROA), Return On Equity (ROE) dan Beban Operasional Terhadap Pendapatan Operasinal (BOPO).

ROA is the ratio betweeen net income by asset. (Salhuteru \& Wattimena, 2015).

ROE digunakan untuk mengukur kemampuan perusahaan menghasilkan laba dari total equity atau modal. Semakin tinggi ROE akan semakin baik, karena tingkat pengembalian investasi dari para pemegang saham ke perusahaan lewat pembagian deviden akan semakin besar.

Efisiensi operasi diukur dengan membandingkan total biaya operasi dengan total pendapatan operasi atau sering menggunakan istilah BOPO. Rasio ini bertujuan mengukur kemampuan pendapatan operasional dalam menutupi biaya operasional.

Bank Indonesia menetapkan angka terbaik untuk rasio BOPO adalah dibawah $90 \%$ karena jika rasio BOPO melebihi $90 \%$ hingga mendekati angka 100\% maka Bank tersebut tidak efisien dalam menjalankan operasinya. (Widati, 2012)

Secara matematis, untuk menghitung ROA, ROE, dan BOPO adalah sebagai berikut.

$$
\begin{aligned}
& \text { R0A }=\frac{\text { LABA SEBELUM PAJAK }}{\text { RATA-RATA TOTALASET }} \times 100 \% \\
& \text { ROE }=\frac{\text { LABA SEBELLMPAJAK }}{\text { RATA-RATA TOTAL EQUTTY }} \times 100 \% \\
& \text { BOP0 }=\frac{\text { TOTAL BEBAN OPERASIONAL }}{\text { TOTALPENDAPATAN OPS }} \times 100 \%
\end{aligned}
$$

\section{LIQUIDITY}

It emphasizes that "the liquidity expresses the degree towhich a bank is capable of fulfilling its respective obligations". Banks makes money by mobilizing short-term deposits at lower interest rate, and lending or investing these funds in long-term at higher rates, so it is hazardous for banks mismatching their lending interest rate. (Sandhya, 2014).

Sejak tanggal 25 Juni 2015, lewat PBI No. 17/11/PBI/2015 Tentang Perubahan Atas Peraturan Bank Indonesia No. 15/15/PBI/2013 Tentang Giro Wajib Minimum Bank Umum Dalam Rupiah Dan Dalam Valuta Asing Bagi Bank Umum Konvensional, Bank Indonesia mengubah kebijakan/peraturan mengenai Loan To Deposit Ratio (LDR) menjadi Loan to Funding Ratio (LFR) adalah rasio kredit yang diberikan kepada pihak ketiga dalam Rupiah dan valuta asing, tidak termasuk kredit kepada bank lain, terhadap:

1. Dana pihak ketiga yang mencakup giro, tabungan, dan deposito dalam Rupiah dan valuta asing, tidak termasuk dana antar bank; dan

2. Surat-surat berharga dalam Rupiah dan valuta asing yang memenuhi persyaratan tertentu yang diterbitkan oleh Bank untuk memperoleh sumber pendanaan.

Secara matematis, untuk menghitung LFR adalah sebagai berikut:

$$
\text { KREDIT }
$$

DITERBITKAN 


\section{SENSITIVITY TO MARKET RISK}

Sensitivity to market risk is rated based upon, but not limited to, an assessment of the following evaluation factors: the sensitivity of the financial institution's earnings or the economic value of its capital to adverse changes in interest rates, foreign exchange rates, commodity prices, or equity prices, the ability of management to identify, measure, monitor, and control exposure to market risk given the institution's size, complexity, and risk profile, the nature and complexity of interest rate risk exposure arising from nontrading positions. (Ferrouhi, 2014)

Perhitungan sensivitas terhadap risiko pasar diatur oleh Otoritas Jasa Keuangan lewat Surat Edaran Otoritas Jasa Keuangan No. 38/SEOJK.03/2016 Tanggal 08 September 2016 Tentang Pedoman Penggunaan Metode Standar Dalam Perhitungan Kewajiban Penyediaan Modal Minimum Bank Umum Dengan Memperhitungkan Risiko Pasar yaitu sebagai berikut.

1. Perhitungan Risiko Pasar mencakup perhitungan risiko suku bunga dan risiko nilai tukar termasuk risiko perubahan harga option.

2. Perhitungan risiko suku bunga dilakukan terhadap posisi instrumen keuangan dalam Trading Book yang terekspos risiko suku bunga.

3. Perhitungan risiko nilai tukar dilakukan terhadap posisi valuta asing dalam Trading Book dan Banking Book yang terekspos risiko nilai tukar.

4. Perhitungan risiko ekuitas bagi Bank secara konsolidasi dengan Perusahaan Anak dilakukan terhadap posisi instrumen keuangan dalam Trading Book yang terekspos risiko ekuitas.

5. Perhitungan risiko komoditas bagi Bank secara konsolidasi dengan Perusahaan Anak dilakukan terhadap posisi instrumen keuangan dalam Trading Book dan Banking Book yang terekspos risiko komoditas.

Jenis-jenis bank yang ada di Indonesia diatur dalam Undang-Undang No. 10 Tahun 1998. Dilihat dari segi kepemilikannya jenis bank terdiri atas bank nasional (dibedakan menjadi dua yaitu nasional maupun bank pembangunan daerah), bank campuran, dan bank asing. Perbedaan jenis kepemilikan ini menimbulkan perbedaan terhadap kemampuan pembiayaan, teknologi yang digunakan oleh masing-masing bank, dan jaringan yang semuanya berdampak pada kinerja perbankan tersebut. Sehingga menimbulkan pertanyaan "apakah terdapat perbedaan kinerja antara bank nasional, bank pembangunan daerah, bank swasta nasional, bank campuran, dan bank asing?" 


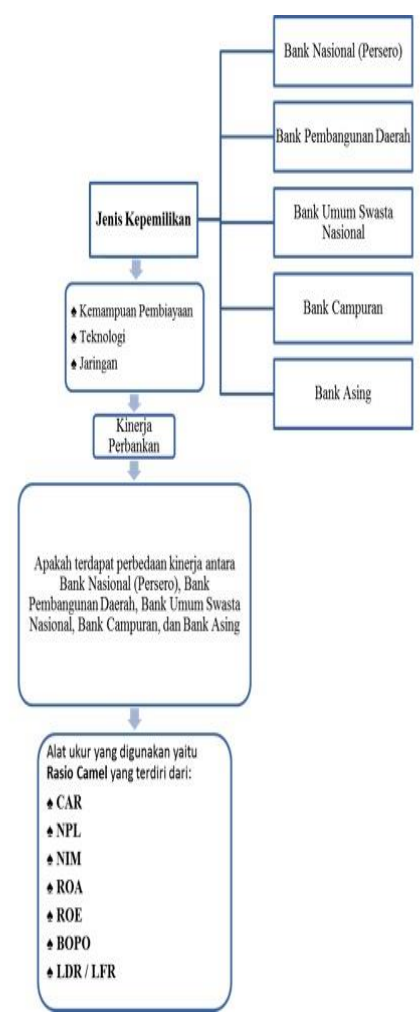

Gambar 1: Kerangka Konseptual Pemikiran

Penelitian ini menyajikan tentang analisa perbandingan kinerja berdasarkan CAMELS Pada Bank Nasional, Bank Pembangunan Daerah, Bank Swasta Nasional, Bank Campuran, dan Bank Asing yang berada di Indonesia, yaitu terdaftar pada Otoritas Jasa Keuangan periode 20102015. Dengan rumusan hipotesa sebagai berikut.

$\mathrm{H}_{1}$ Terdapat perbedaan kinerja berdasarkan CAMELS antara Bank Nasional dan Bank Pembangunan Daerah. Nasional.

$\mathrm{H}_{2}$ Terdapat perbedaan kinerja berdasarkan CAMELS antara Bank Nasional dan Bank Swasta

$\mathrm{H}_{3}$ Terdapat perbedaan kinerja berdasarkan CAMELS antara Bank Campuran dan Bank Asing.

\section{Metode Penelitian}

Penelitian yang digunakan dalam penelitian ini adalah penelitian kuantitatif dengan metode statistic parametrik uji beda rata-rata (t-test). Uji t merupakan jenis pengujian statistik untuk mengetahui apakan terdapat perbedaan nilai dari yang diperkirakan dengan nilai hasil perhitungan statistik.

Syarat untuk melakukan uji $\mathrm{t}$ antara lain nilai parameter diketahui/ditentukan; dan distribusi normal. Uji yang digunakan dalam penelitian ini adalah independent-sample $t$ test. Independent sample $t$ test digunakan untuk mengetahui signifikansi beda rata-rata dua kelompok. Test ini digunakan untuk menguji pengaruh variable indepdenden terhadap variabel dependen.

Populasi dalam penelitian ini adalah seluruh bank (baik bank nasional, bank pembangunan daerah, bank swasta nasional, bank campuran dan bank asing) yang terdaftar di website Otoritas Jasa Keuangan sebanyak 153 bank. Dengan menggunakan purposive sampling dengan pemilihan kriteria adalah sebagai berikut.

1. Perbankan yang melakukan publikasi laporan keuangan 5 tahun berturut-turut dari 20102015;

2. Laporan keuangan yang mempunyai tahun buku yang berakhir 31 Desember agar menghindari adanya pengaruh waktu parsial dalam perhitungan rasio keuangan. 
Berdasarkan kriteria tersebut dan sehubungan dengan bank nasional yang terdaftar dalam website Otoritas Jasa Keuangan adalah 4 bank (yang terdaftar di Otoritas Jasa Keuangan terdapat 5 Bank, namun salah satu bank, yaitu Bank Ekspor Indonesia tidak lagi beroperasi sejak tahun 2009, maka bank nasional yang resmi beroperasi adalah 4 bank), maka diambil sampel sebanyak 20 bank dengan perincian: 4 bank nasional, 4 bank pembangunan daerah, 4 bank swasta nasional, 4 bank campuran, dan 4 bank asing. Dengan rincian masing-masing sampel adalah sebagai berikut.

Tabel 1. Rincian Sampel Bank Nasional

\begin{tabular}{|c|l|}
\hline No & \multicolumn{1}{|c|}{ Nama Bank } \\
\hline 1 & PT. Bank Mandiri (Persero), Tbk \\
\hline 2 & PT. Bank Negara Indonesia (Persero), Tbk \\
\hline 3 & PT. Bank Rakyat Indonesia (Persero), Tbk \\
\hline 4 & PT. Bank Tabungan Negara (Persero), Tbk \\
\hline
\end{tabular}

Sumber: Otoritas Jasa Keuangan (2016)

Tabel 2: Rincian Sampel Bank Pembangunan Daerah

\begin{tabular}{|c|l|}
\hline No & \multicolumn{1}{|c|}{ Nama Bank } \\
\hline 1 & PT. BPD Sulawesi Utara \\
\hline 2 & PT. BPD Papua \\
\hline 3 & PT. BPD Bali \\
\hline 4 & PT. BPD Jawa Barat dan Banten, Tbk \\
\hline
\end{tabular}

Sumber: Otoritas Jasa Keuangan (2016)

Tabel 3: Rincian Sampel Bank Swasta Nasional

\begin{tabular}{|c|l|}
\hline No & \multicolumn{1}{|c|}{ Nama Bank } \\
\hline 1 & PT. Bank Central Asia, Tbk \\
\hline 2 & PT. Bank UOB Indonesia \\
\hline 3 & PT. Bank OCBC NISP, Tbk \\
\hline 4 & PT. Bank Mega, Tbk \\
\hline
\end{tabular}

Sumber: Otoritas Jasa Keuangan (2016)

Tabel 4: Rincian Sampel Bank Campuran

\begin{tabular}{|c|l|}
\hline No & \multicolumn{1}{|c|}{ Nama Bank } \\
\hline 1 & PT. Bank Commonwealth \\
\hline 2 & PT. Bank DBS Indonesia \\
\hline 3 & PT. Bank Mizuho Indonesia \\
\hline 4 & PT. Bank Rabobank Internatinal Indonesia \\
\hline
\end{tabular}

Sumber: Otoritas Jasa Keuangan (2016)

Tabel 5: Rincian Sampel Bank Asing

\begin{tabular}{|c|l|}
\hline No & \multicolumn{1}{|c|}{ Nama Bank } \\
\hline 1 & Citibank, NA \\
\hline 2 & The Hongkong And Shanghai Banking Corp \\
\hline 3 & JP. Morgan Chase Bank, N.A \\
\hline 4 & Standard Chartered Bank \\
\hline
\end{tabular}

Sumber: Otoritas Jasa Keuangan (2016)

\section{Hasil Penelitian Dan Pembahasan}

Hasil Penelitian

\section{Uji beda antara Bank Nasional dan Bank Pembangunan Daerah}

Berdasarkan hasil penelitian, maka perbandingan setiap variable CAMEL untuk Bank Nasional dengan Bank Pembangunan Daerah diuraikan dengan menggunakan statistik deskriptif seperti yang terlihat pada Tabel 5 


\begin{tabular}{|c|c|c|c|c|c|}
\hline \multicolumn{6}{|c|}{ Group Statistics } \\
\hline & DUMMY & $\mathrm{N}$ & Mean & $\begin{array}{c}\text { Std. } \\
\text { Deviation }\end{array}$ & $\begin{array}{c}\text { Std. Error } \\
\text { Mean }\end{array}$ \\
\hline \multirow{3}{*}{ CAR } & Bank Nasional & 24 & 16.5121 & 1.79845 & .36711 \\
\hline & Bank Pembangunan & 24 & 17.5017 & 3.93156 & 80253 \\
\hline & $\begin{array}{l}\text { Daerah } \\
\text { Bank Nasional }\end{array}$ & 24 & 2.6225 & .88571 & 18080 \\
\hline NPL & $\begin{array}{l}\text { Bank Pembangunan } \\
\text { Daerah }\end{array}$ & 24 & 1.9204 & 2.24561 & .45838 \\
\hline \multirow[b]{2}{*}{ NIM } & Bank Nasional & 24 & 6.5213 & 1.58415 & .32336 \\
\hline & Bank Pembangunan & 24 & 7.9346 & 1.39082 & .28390 \\
\hline \multirow[b]{2}{*}{ ROA } & Bank Nasional & 24 & 3.2496 & 1.14953 & .23465 \\
\hline & $\begin{array}{l}\text { Bank Pembangunan } \\
\text { Daerah }\end{array}$ & 24 & 2.8429 & .80698 & .16472 \\
\hline \multirow{2}{*}{ ROE } & Bank Nasional & 24 & 25.3404 & 8.70327 & 1.77655 \\
\hline & $\begin{array}{l}\text { Bank Pembangunan } \\
\text { Daerah }\end{array}$ & 24 & 24.2558 & 6.91982 & 1.41250 \\
\hline \multirow{2}{*}{ BOPO } & Bank Nasional & 24 & 71.6300 & 8.23268 & 1.68049 \\
\hline & $\begin{array}{l}\text { Bank Pembangunan } \\
\text { Daerah }\end{array}$ & 24 & 76.9354 & 8.65854 & 1.76742 \\
\hline \multirow[b]{2}{*}{ LDR } & Bank Nasional & 24 & 86.1658 & 13.11332 & 2.67674 \\
\hline & $\begin{array}{l}\text { Bank Pembangunan } \\
\text { Daerah }\end{array}$ & 24 & 85.7450 & 16.72360 & 3.41369 \\
\hline
\end{tabular}

Sumber: Data Olahan (2016)

Uraian setiap variabel adalah sebagai berikut.

1. Nilai rata-rata CAR untuk Bank Nasional adalah 16.51 sedangkan Bank Pembangunan Daerah memiliki nilai rata-rata 17.50 .

2. Nilai rata-rata NPL untuk Bank Nasional adalah 2.62 sedangkan untuk Bank Pembangunan Daerah adalah 1.92.

3. Nilai rata-rata NIM untuk Bank Nasional adalah 6.52 sedangkan Bank Pembangunan Daerah adalah 7.93 .

4. Nilai rata-rata ROA untuk Bank Nasional adalah 3.24 sedangkan Bank Pembangunan Daerah adalah 2.84 .

5. Nilai rata-rata ROE untuk Bank Nasional adalah 25.34 sedangkan Bank Pembangunan Daerah adalah 24.25.

6. Nilai rata-rata BOPO untuk Bank Nasional adalah 71.63 sedangkan Bank Pembangunan Daerah adalah 76.93.

7. Nilai rata-rata LDR/LFR untuk Bank Nasional adalah 86.16 sedangkan Bank Pembangunan Daerah adalah 85.74.

\section{Uji Beda Antara Bank Nasional dan Bank Swasta Nasional}

Berdasarkan hasil penelitian, maka perbandingan setiap variabel CAMEL untuk Bank Nasional dengan Bank Swasta Nasional diuraikan dengan menggunakan statistik deskriptif seperti yang terlihat pada Tabel 6 


\begin{tabular}{|c|c|c|c|c|c|}
\hline \multicolumn{6}{|c|}{ Group Statistics } \\
\hline & DUMMY & $\mathrm{N}$ & Mean & $\begin{array}{c}\text { Std. } \\
\text { Deviation }\end{array}$ & $\begin{array}{l}\text { Std. Error } \\
\text { Mean }\end{array}$ \\
\hline & Bank Nasional & 24 & 16.5121 & 1.79845 & .36711 \\
\hline CAR & Bank Swasta & 24 & 16.4304 & 2.62717 & .53627 \\
\hline & Bank Nasional & 24 & 2.6225 & .88571 & .18080 \\
\hline NPL & Bank Swasta & 24 & 1.4775 & .86808 & .17720 \\
\hline & $\begin{array}{l}\text { Nasional } \\
\text { Bank Nasional }\end{array}$ & 24 & 6.5213 & 1.58415 & .32336 \\
\hline NIM & $\begin{array}{l}\text { Bank Swasta } \\
\text { Nasional }\end{array}$ & 24 & 5.2058 & .84778 & .17305 \\
\hline & Bank Nasional & 24 & 3.2496 & 1.14953 & .23465 \\
\hline ROA & Bank Swasta & 24 & 2.3696 & .99636 & .20338 \\
\hline & Bank Nasional & 24 & 25.3404 & 8.70327 & 1.77655 \\
\hline ROE & $\begin{array}{l}\text { Bank Swasta } \\
\text { Nasional }\end{array}$ & 24 & 17.5254 & 9.07742 & 1.85292 \\
\hline & Bank Nasional & 24 & 71.6300 & 8.23268 & 1.68049 \\
\hline BOPO & $\begin{array}{l}\text { Bank Swasta } \\
\text { Nasional }\end{array}$ & 24 & 76.9408 & 10.28824 & 2.10008 \\
\hline & Bank Nasional & 24 & 86.1658 & 13.11332 & 2.67674 \\
\hline LDR & $\begin{array}{l}\text { Bank Swasta } \\
\text { Nasional }\end{array}$ & 24 & 78.1704 & 15.44160 & 3.15200 \\
\hline
\end{tabular}

Sumber: Data Olahan (2016)

Untuk setiap variabel adalah sebagai berikut.

1. Nilai rata-rata CAR untuk Bank Nasional adalah 16.51 sedangkan Bank Swasta Nasional memiliki nilai rata-rata 16.43 .

2. Nilai rata-rata NPL untuk Bank Nasional adalah 2.62 sedangkan untuk Bank Swasta Nasional adalah 1.47.

3. Nilai rata-rata NIM untuk Bank Nasional adalah 6.52 sedangkan Bank Swasta Nasional adalah 5.20.

4. Nilai rata-rata ROA untuk Bank Nasional adalah 3.24 sedangkan Bank Swasta Nasional adalah 2.36 .

5. Nilai rata-rata ROE untuk Bank Nasional adalah 25.34 sedangkan Bank Swasta Nasional adalah 17.52 .

6. Nilai rata-rata BOPO untuk Bank Nasional adalah 71.63 sedangkan Bank Swasta Nasional adalah 76.94.

7. Nilai rata-rata LDR/LFR untuk Bank Nasional adalah 86.16 sedangkan Bank Swasta Nasional adalah 78.17.

\section{Uji Beda Antara Bank Campuran dan Bank Asing.}

Berdasarkan hasil penelitian, maka perbandingan setiap variabel CAMEL untuk Bank Campuran dengan Bank Swasta Asing diuraikan dengan menggunakan statistik deskriptif seperti yang terlihat pada Tabel 7 


\begin{tabular}{|rl|r|r|r|r|}
\hline \multicolumn{7}{|c|}{ Group Statistics } \\
\hline \multirow{2}{*}{ CAR } & DUMMY & N & Mean & Std. Deviation & \multicolumn{1}{c|}{$\begin{array}{c}\text { Std. Error } \\
\text { Mean }\end{array}$} \\
\hline \multirow{2}{*}{ BPL Campuran } & 24 & 17.0354 & 3.79556 & .77477 \\
& Bank Asing & 24 & 23.5396 & 8.56746 & 1.74882 \\
& Bank Campuran & 24 & 2.6762 & 1.69720 & .34644 \\
& Bank Asing & 24 & 2.1854 & 2.30258 & .47001 \\
& Bank Campuran & 24 & 3.9300 & .95878 & .19571 \\
NIM & Bank Asing & 24 & 3.9975 & 1.03530 & .21133 \\
& Bank Campuran & 24 & .9163 & 1.55643 & .31771 \\
ROA & Bank Asing & 24 & 3.1329 & 1.74230 & .35565 \\
& Bank Campuran & 24 & 4.3296 & 13.81310 & 2.81959 \\
ROE & Bank Asing & 24 & 13.8054 & 7.37627 & 1.50568 \\
& Bank Campuran & 24 & 85.1996 & 22.70355 & 4.63434 \\
BOPO & Bank Asing & 24 & 77.5192 & 21.72650 & 4.43490 \\
& Bank Campuran & 24 & 124.3479 & 54.64061 & 11.15347 \\
LDR & Bank Asing & 24 & 85.6442 & 17.48167 & 3.56843 \\
\hline
\end{tabular}

Sumber: Data Olahan (2016)

Untuk setiap variabel adalah sebagai berikut.

1. Nilai rata-rata CAR untuk Bank Campuran adalah 17.03 sedangkan Bank Asing memiliki nilai rata-rata 23.53.

2. Nilai rata-rata NPL adalah 2.67 sedangkan untuk Bank Asing adalah 2.18.

3. Nilai rata-rata NIM untuk Bank Campuran adalah 3.93 sedangkan Bank Asing adalah 3.99.

4. Nilai rata-rata ROA untuk Bank Campuran adalah 0.93 sedangkan Bank Swasta Nasional adalah 3.13 .

5. Nilai rata-rata ROE untuk Bank Campuran adalah 4.32 sedangkan Bank Asing adalah 13.80 .

6. Nilai rata-rata BOPO untuk Bank Campuran adalah 85.19 sedangkan Bank Asing adalah 77.51.

7. Nilai rata-rata LDR/LFR untuk Bank Campuran adalah 124.34 sedangkan Bank Asing adalah 85.64 .

\section{Pembahasan}

Pengujian Hipotesis 1

Hipotesis $1\left(\mathrm{H}_{1}\right)$ menyatakan terdapat perbedaan kinerja berdasarkan CAMELS antara Bank Nasional dan Bank Pembangunan Daerah. Berdasarkan hasil pengujian dengan menggunakan uji beda rata-rata, maka hasil pengujian untuk perbandingan kinerja pada Bank Nasional dan Bank Pembangunan Daerah dapat dilihat pada Tabel 8 


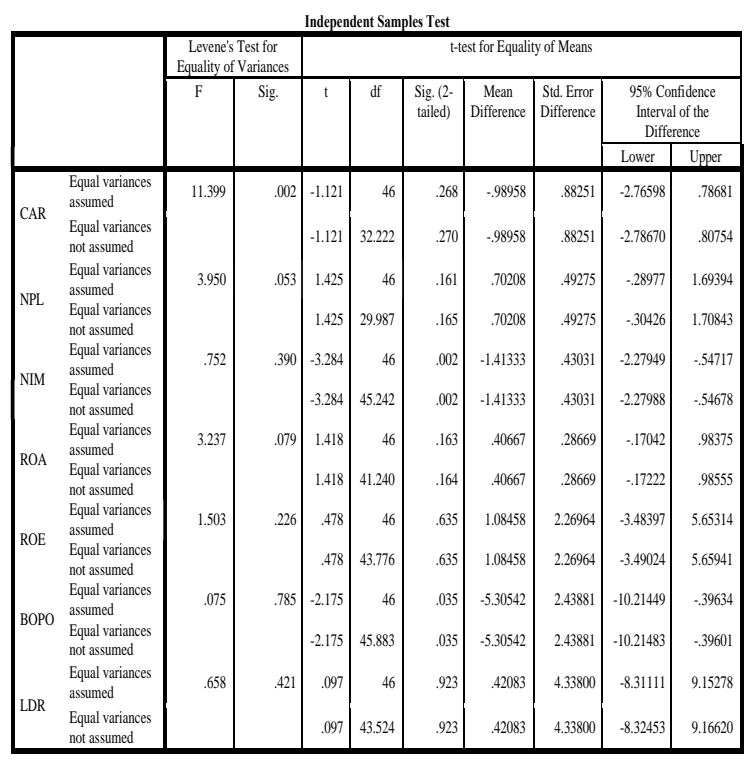

Sumber: Data Olahan (2016)

Nilai rata-rata CAR untuk Bank Nasional adalah 16.51 sedangkan Bank Pembangunan Daerah memiliki nilai adalah 17.50. Uji Levene menunjukkan nilai F sebesar 11.399 dengan signifikansi 0.002 yang menunjukkan bahwa variansi data tidak sama (equal variances not assumed), sehingga hasil perbedaan antara CAR Bank Nasional dan Bank Pembangunan Daerah adalah tidak signifikan berbeda yaitu sebesar 0.98 (tingkat signifikansi $<1$ ), namun masih tergolong dalam kriteria sehat $(\geq 8 \%)$. Dengan demikian rasio CAR Bank Pembangunan Daerah yang lebih tinggi dibandingkan dengan Bank Nasional menunjukkan semakin baiknya kemampuan Bank Pembangunan Daerah dalam menanggung dan menyerap risiko yang ada, sehingga Bank Pembangunan Daerah dapat lebih leluasa dalam melaksanakan ekspansi aktiva produktif dalam memperoleh laba yang maksimal.

Nilai NPL Bank Nasional adalah 2.62 sedangkan Bank Pembangunan Daerah adalah 1.92. Uji Levene menunjukkan nilai $F$ sebesar 3.950 dengan signifikansi 0.053 yang menunjukkan bahwa variansi data adalah sama (equal variances assumed). Hasil perbedaan antara NPL Bank Nasional dan Bank Pembangunan Daerah adalah tidak signifikan berbeda yaitu sebesar 0.70 (tingkat signifikansi $<1$ ). Dengan demikian rasio NPL Bank Pembangunan Daerah lebih rendah dibandingkan dengan Bank Nasional menunjukkan tingkat kemampuan Bank Pembangunan Daerah dalam mengelola kredit bermasalah lebih baik. Namun keduanya termasuk dalam kategori sehat (hasil rasio $\leq 6 \%$ ).

Nilai rata-rata NIM untuk Bank Nasional adalah 6.52 sedangkan Bank Pembangunan Daerah adalah 7.93. Uji Levene menunjukkan nilai $F$ sebesar 0.752 dengan signifikansi 0.39 yang menunjukkan bahwa variansi data adalah sama (equal variances assumed). Hasil perbedaan antara NIM Bank Nasional dan Bank Pembangunan Daerah adalah signifikan berbeda karena terdapat perbedaan sebesar 1.413 (tingkat signifikansi $>1$ ), namun masih tergolong dalam kriteria sehat (hasil rasio $\geq 1.5 \%$ ). Rasio NIM Bank Pembangunan Daerah lebih tinggi dibandingkan dengan Bank Nasional menunjukkan semakin baiknya tingkat kemampuan Bank Pembangunan Daerah dalam menghasilkan pendapatan bunga dengan melihat kinerja bank lewat penyaluran aktiva produktif.

Nilai rata-rata ROA untuk Bank Nasional adalah 3.24 sedangkan Bank Pembangunan Daerah adalah 2.84. Uji Levene menunjukkan nilai $F$ sebesar 3.237 dengan signifikansi 0.07 yang menunjukkan bahwa variansi data adalah sama (equal variances assumed). Hasil perbedaan ROA Bank Nasional dan Bank Pembangunan Daerah adalah tidak signifikan berbeda yaitu sebesar 0.406 (tingkat signifikansi <1). Nilai rata-rata ROA Bank Nasional lebih tinggi dibandingkan dengan Bank Pembangunan Daerah mencerminkan peningkatan keuntungan 
yang dicapai, dan posisi yang semakin baik dari segi penggunaan aset oleh Bank Nasional lebih baik dibandingkan dengan Bank Pembangunan Daerah.

Nilai rata-rata ROE untuk Bank Nasional adalah 25.34 sedangkan Bank Pembangunan Daerah adalah 24.25. Uji Levene menunjukkan nilai $F$ sebesar 1.503 dengan signifikansi 0.226 yang menunjukkan bahwa variansi data adalah sama (equal variances assumed). Hasil perbedaan ROE Bank Nasional dan Bank Pembangunan Daerah adalah signifikan berbeda karena terdapat perbedaan sebesar 1.084 (tingkat signifikansi $>1$ ). Nilai rata-rata ROE Bank Nasional lebih tinggi dibandingkan dengan Bank Pembangunan Daerah mencerminkan besarnya pengembalian terhadap investasi kepada pemilik perusahaan yang berasal dari laba (pembayaran deviden) oleh Bank Nasional lebih besar daripada Bank Pembangunan Daerah.

Nilai rata-rata BOPO untuk Bank Nasional adalah 71.63 sedangkan Bank Pembangunan Daerah adalah 76.93. Uji Levene menunjukkan nilai $F$ sebesar 0.075 dengan signifikansi 0.785 yang menunjukkan bahwa variansi data adalah sama (equal variances assumed). Hasil perbedaan BOPO Bank Nasional dan Bank Pembangunan Daerah adalah signifikan berbeda karena terdapat perbedaan sebesar 5.305 (tingkat signifikansi $>1$ ). Nilai rata-rata BOPO Bank Nasional yang lebih rendah dibandingkan dengan Bank Pembangunan Daerah mencerminkan tingkat efisiensi dalam pengelolaan biaya yang dilakukan oleh Bank Nasional lebih efisien dibandingkan Bank Pembangunan Daerah. Dengan semakin rendahnya nilai BOPO, maka berdampak pada peningkatan ROA dan ROE Bank tersebut.

Nilai rata-rata LDR/LFR untuk Bank Nasional adalah 86.16 sedangkan Bank Pembangunan Daerah adalah 85.74. Uji Levene menunjukkan nilai $F$ sebesar 0.658 dengan signifikansi 0.421 yang menunjukkan bahwa variansi data adalah sama (equal variances assumed). Hasil perbedaan LDR/LFR Bank Nasional dan Bank Pembangunan Daerah tidak signifikan berbeda yaitu sebesar 0.423 (tingkat signifikansi <1). Rasio LDR/LFR baik yang dimiliki oleh Bank Nasional maupun Bank Pembangunan Daerah masih tergolong dalam kriteria sehat dan memenuhi ketentuan regulasi yang ditetapkan (hasil rasio $>80 \%$ sampai dengan $<92 \%$ ). Nilai rata-rata LDR/LFR Bank Pembangunan Daerah lebih rendah dibandingkan dengan Bank Nasional menunjukkan tingginya likuiditas dan tingkat kepercayaan masyarakat kepada Bank Pembangunan Daerah. Hal ini juga bisa dipahami karena Bank Pembangunan Daerah mengelola kas daerah milik Pemerintah Daerah serta bunga deposito yang ditawarkan lebih tinggi daripada Bank Nasional.

Pengujian Hipotesis 2

Hipotesis $2\left(\mathrm{H}_{2}\right)$ menyatakan terdapat perbedaan kinerja berdasarkan CAMELS antara Bank Nasional dan Bank Swasta Nasional. Berdasarkan hasil pengujian dengan menggunakan uji beda rata-rata, maka hasil pengujian untuk perbandingan kinerja pada Bank Nasional dan Swasta Nasional dapat dilihat pada Tabel 9 


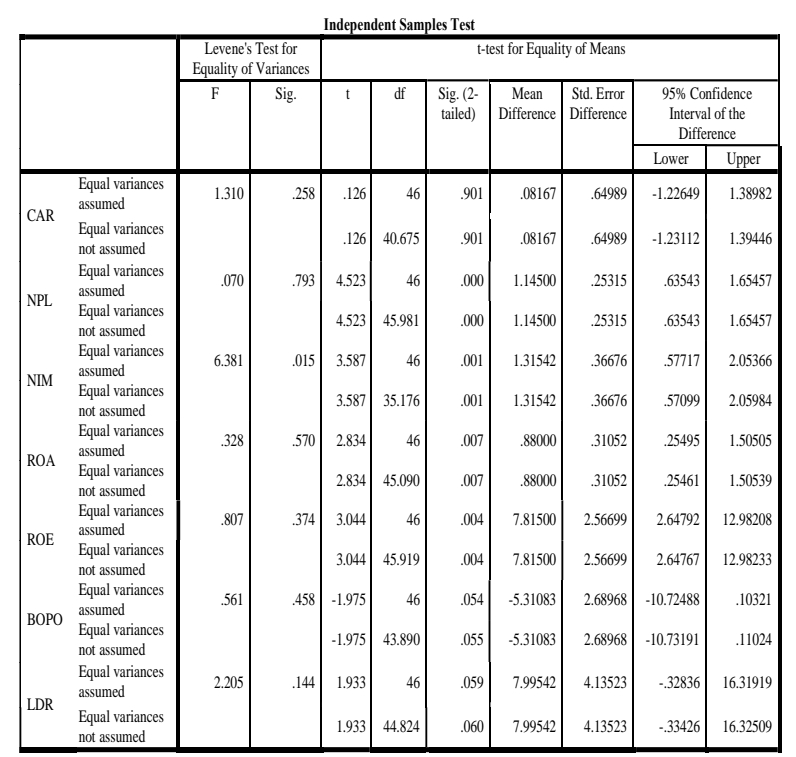

Sumber: Data Olahan (2016)

Nilai rata-rata CAR untuk Bank Nasional adalah 16.51 sedangkan Bank Swasta Nasional memiliki nilai adalah 16.43. Uji Levene menunjukkan nilai $F$ sebesar 1.310 dengan signifikansi 0.258 yang menunjukkan bahwa variansi data adalah sama (equal variances assumed). Hasil perbedaan antara CAR Bank Nasional dan Bank Swasta Nasional adalah tidak signifikan berbeda yaitu sebesar 0.081 (tingkat signifikansi $<1$ ), namun masih tergolong dalam kriteria sehat $(\geq 8 \%)$. Dengan demikian rasio CAR Bank Nasional yang lebih tinggi dibandingkan dengan Bank Swasta Nasional menunjukkan kemampuan Bank Nasional dalam menanggung dan menyerap risiko yang ada, sehingga Bank Nasional dapat lebih leluasa dalam melaksanakan ekspansi aktiva produktif dalam memperoleh laba yang maksimal.

Nilai NPL Bank Nasional adalah 2.62 sedangkan Bank Swasta Nasional adalah 1.47. Uji Levene menunjukkan nilai $\mathrm{F}$ sebesar 0.070 dengan signifikansi 0.793 yang menunjukkan bahwa variansi data adalah sama (equal variances assumed). Hasil perbedaan antara NPL Bank Nasional dan Bank Swasta Nasional adalah signifikan berbeda yaitu sebesar 1.145 (tingkat signifikansi >1). Dengan demikian rasio NPL Bank Swasta Nasional lebih rendah dibandingkan dengan Bank Nasional menunjukkan tingkat kemampuan Bank Swasta Nasional dalam mengelola kredit bermasalah lebih baik. namun keduanya termasuk dalam kategori sehat (hasil rasio $\leq 6 \%$ ).

Nilai rata-rata NIM untuk Bank Nasional adalah 6.52 sedangkan Bank Swasta Nasional adalah 5.20. Uji Levene menunjukkan nilai $F$ sebesar 6.381 dengan signifikansi 0.015 yang menunjukkan bahwa variansi data adalah tidak sama (equal variances not assumed). Hasil perbedaan antara NIM Bank Nasional dan Bank Swasta Nasional adalah signifikan berbeda karena terdapat perbedaan sebesar 1.315 (tingkat signifikansi $>1$ ), namun masih tergolong dalam kriteria sehat (hasil rasio $\geq 1.5 \%$ ). Rasio NIM Bank Nasional lebih tinggi dibandingkan dengan Bank Swasta Nasional menunjukkan semakin baiknya tingkat kemampuan Bank Nasional dalam menghasilkan pendapatan bunga dengan melihat kinerja bank lewat penyaluran aktiva produktif.

Nilai rata-rata ROA untuk Bank Nasional adalah 3.24 sedangkan Bank Swasta Nasional adalah 2.36. Uji Levene menunjukkan nilai $F$ sebesar 0.328 dengan signifikansi 0.570 yang menunjukkan bahwa variansi data adalah sama (equal variances assumed). Hasil perbedaan ROA Bank Nasional dan Bank Swasta Nasional adalah tidak signifikan berbeda yaitu sebesar 0.88 (tingkat signifikansi <1). Nilai rata-rata ROA Bank Nasional lebih tinggi dibandingkan dengan Bank Swasta Nasional mencerminkan peningkatan keuntungan yang dicapai, dan posisi yang semakin baik dari segi penggunaan aset oleh Bank Nasional lebih baik dibandingkan dengan Bank Swasta Nasional. 
Nilai rata-rata ROE untuk Bank Nasional adalah 25.34 sedangkan Bank Swasta Nasional adalah 17.52. Uji Levene menunjukkan nilai $F$ sebesar 0.807 dengan signifikansi 0.374 yang menunjukkan bahwa variansi data adalah sama (equal variances assumed). Hasil perbedaan ROE Bank Nasional dan Bank Swasta Nasional adalah signifikan berbeda karena terdapat perbedaan sebesar 7.81 (tingkat signifikansi >1). Nilai rata-rata ROE Bank Nasional lebih tinggi dibandingkan dengan Bank Swasta Nasional mencerminkan besarnya pengembalian terhadap investasi kepada pemilik perusahaan yang berasal dari laba (pembayaran deviden) oleh Bank Nasional lebih besar daripada Bank Swasta Nasional.

Nilai rata-rata BOPO untuk Bank Nasional adalah 71.63 sedangkan Bank Swasta Nasional adalah 76.94. Uji Levene menunjukkan nilai $F$ sebesar 0.561 dengan signifikansi 0.458 yang menunjukkan bahwa variansi data adalah sama (equal variances assumed). Hasil perbedaan BOPO Bank Nasional dan Bank Swasta Nasional adalah signifikan berbeda karena terdapat perbedaan sebesar 5.310 (tingkat signifikansi $>1$ ). Nilai rata-rata BOPO Bank Nasional yang lebih rendah dibandingkan dengan Bank Swasta Nasional mencerminkan tingkat efisiensi dalam pengelolaan biaya yang dilakukan oleh Bank Nasional lebih efisien dibandingkan Bank Swasta Nasional. Dengan semakin rendahnya nilai BOPO, maka berdampak pada peningkatan ROA dan ROE Bank tersebut.

Nilai rata-rata LDR/LFR untuk Bank Nasional adalah 86.16 sedangkan Bank Swasta Nasional adalah 78.17. Uji Levene menunjukkan nilai $F$ sebesar 2.205 dengan signifikansi 0.144 yang menunjukkan bahwa variansi data adalah sama (equal variances assumed). Hasil perbedaan LDR/LFR Bank Nasional dan Bank Swasta Nasional signifikan berbeda yaitu sebesar 7.995 (tingkat signifikansi $>1$ ). Rasio LDR/LFR baik yang dimiliki oleh Bank Nasional masih tergolong dalam kriteria sehat dan memenuhi ketentuan regulasi yang ditetapkan, namun rasio LDR/LFR Bank Swasta Nasional berada di batas bawah yang ditetapkan pihak regulator dan telah dikenakan disinsentif GWM karena melewati batas bawah LDR/LFR, sehingga Bank Swasta Nasional perlu memperbesar penggunaan dana yang telah berhasil dihimpun ke aktiva produktif utama Bank, yaitu penyaluran kredit kepada nasabah dengan prinsip kehati-hatian (hasil rasio $>80 \%$ sampai dengan $<92 \%$ ). Nilai rata-rata LDR/LFR Bank Swasta Nasional lebih rendah dibandingkan dengan Bank Nasional menunjukkan tingginya likuiditas dan tingkat kepercayaan masyarakat kepada Bank Swasta Nasional. Hal ini juga bisa dipahami karena layanan dan teknologi (e-chanel) Bank Swasta Nasional lebih unggul daripada Bank Nasional.

Pengujian Hipotesis 3

Hipotesis $3\left(\mathrm{H}_{3}\right)$ menyatakan terdapat perbedaan kinerja antara Bank Campuran dan Bank Asing. Berdasarkan hasil pengujian dengan menggunakan uji beda rata-rata, maka hasil pengujian untuk perbandingan kinerja pada Bank Campuran dan Bank Asing dapat dilihat pada Tabel 10 


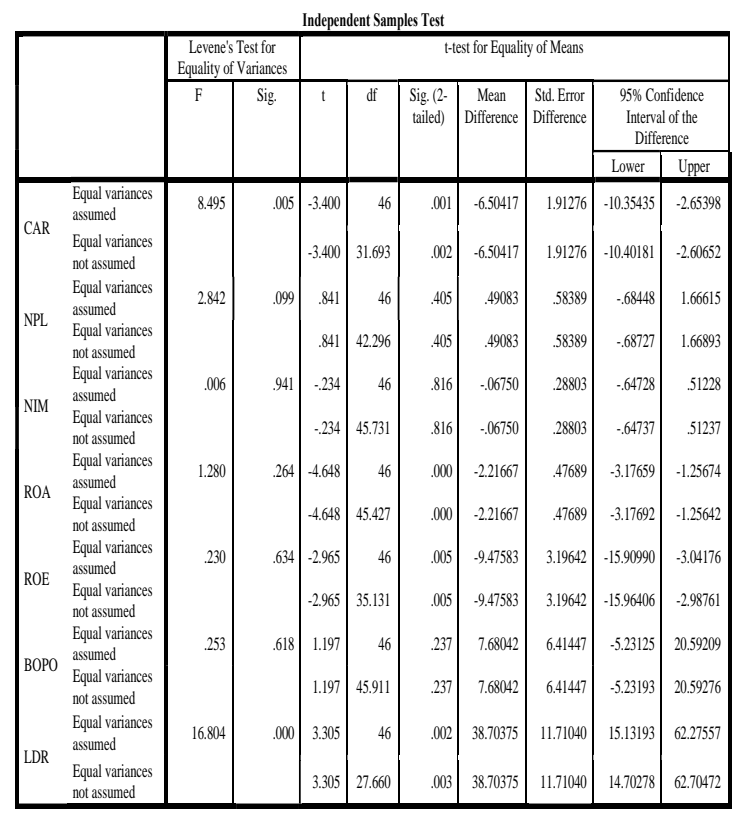

Sumber: Data Olahan (2016)

Nilai rata-rata CAR untuk Bank Campuran adalah 17.03 sedangkan Bank Asing memiliki nilai adalah 23.53. Uji Levene menunjukkan nilai $F$ sebesar 8.49 dengan signifikansi 0.005 yang menunjukkan bahwa variansi data adalah tidak sama (equal variances not assumed). Hasil perbedaan antara CAR Bank Campuran dan Bank Asing adalah signifikan berbeda yaitu sebesar 6.504 (tingkat signifikansi $<1$ ), namun masih tergolong dalam kriteria sehat $(\geq 8 \%)$. Dengan demikian rasio CAR Bank Asing yang lebih tinggi dibandingkan dengan Bank Campuran menunjukkan kemampuan Bank Asing dalam menanggung dan menyerap risiko yang ada, termasuk kesiapan permodalan Bank Asing dalam melakukan investasi dibidang perbankan Indonesia.

Nilai NPL Bank Campuran adalah 2.67 sedangkan Bank Asing adalah 2.18. Uji Levene menunjukkan nilai $F$ sebesar 2.842 dengan signifikansi 0.099 yang menunjukkan bahwa variansi data adalah sama (equal variances assumed). Hasil perbedaan antara NPL Bank Campuran dan Bank Asing adalah tidak signifikan berbeda yaitu sebesar 0.490 (tingkat signifikansi <1). Dengan demikian rasio NPL Bank Asing rendah dibandingkan dengan Bank Campuran menunjukkan tingkat kemampuan Bank Asing dalam mengelola kredit bermasalah lebih baik. Namun keduanya termasuk dalam kategori sehat (hasil rasio $\leq 6 \%$ ).

Nilai rata-rata NIM untuk Bank Campuran adalah 3.93 sedangkan Bank Asing adalah 3.99. Uji Levene menunjukkan nilai $F$ sebesar 0.006 dengan signifikansi 0.941 yang menunjukkan bahwa variansi data adalah sama (equal variances assumed). Hasil perbedaan antara NIM Bank Campuran dan Bank Asing adalah tidak signifikan berbeda yaitu sebesar 0.06 (tingkat signifikansi $<1$ ), namun masih tergolong dalam kriteria sehat (hasil rasio $\geq 1.5 \%$ ). Rasio NIM Asing lebih tinggi dibandingkan dengan Bank Campuran menunjukkan semakin baiknya tingkat kemampuan Bank Asing dalam menghasilkan pendapatan bunga dengan melihat kinerja bank lewat penyaluran aktiva produktif.

Nilai rata-rata ROA untuk Bank Campuran adalah 0.91 sedangkan Bank Asing adalah 3.13. Uji Levene menunjukkan nilai F sebesar 1.280 dengan signifikansi 0.264 yang menunjukkan bahwa variansi data adalah sama (equal variances assumed). Hasil perbedaan ROA Bank Campuran dan Bank Asing adalah signifikan berbeda karena terdapat perbedaan sebesar 2.21 (tingkat signifikansi $>1$ ). Nilai rata-rata ROA Bank Asing lebih tinggi dibandingkan dengan Bank Campuran mencerminkan peningkatan keuntungan yang 
dicapai, dan posisi yang semakin baik dari segi penggunaan aset oleh Bank Asing lebih baik dibandingkan Bank Campuran.

Nilai rata-rata ROE untuk Bank Campuran adalah 4.32 sedangkan Bank Asing adalah 13.80. Uji Levene menunjukkan nilai $\mathrm{F}$ sebesar 0.230 dengan signifikansi 0.634 yang menunjukkan bahwa variansi data adalah sama (equal variances assumed). Hasil perbedaan ROE Bank Campuran dan Bank Asing adalah signifikan berbeda karena terdapat perbedaan sebesar 9.47 (tingkat signifikansi $>1$ ). Nilai rata-rata ROE Bank Asing lebih tinggi dibandingkan dengan Bank Campuran mencerminkan besarnya pengembalian terhadap investasi kepada pemilik perusahaan yang berasal dari laba (pembayaran deviden) oleh Bank Asing lebih besar daripada Bank Campuran.

Nilai rata-rata BOPO untuk Bank Campuran adalah 85.19 sedangkan Bank Asing adalah 77.51. Uji Levene menunjukkan nilai $F$ sebesar 0.253 dengan signifikansi 0.618 yang menunjukkan bahwa variansi data adalah sama (equal variances assumed). Hasil perbedaan BOPO Bank Campuran dan Bank Asing adalah signifikan berbeda karena terdapat perbedaan sebesar 7.68 (tingkat signifikansi $>1$ ). Nilai rata-rata BOPO Bank Asing yang lebih rendah dibandingkan dengan Bank Campuran mencerminkan tingkat efisiensi dalam pengelolaan biaya yang dilakukan oleh Bank Asing lebih efisien dibandingkan Bank Campuran. Dengan semakin rendahnya nilai BOPO, maka berdampak pada peningkatan ROA dan ROE Bank tersebut.

Nilai rata-rata LDR/LFR untuk Bank Campuran adalah 124.34 sedangkan Bank Asing adalah 85.64. Uji Levene menunjukkan nilai $F$ sebesar 16.80 dengan signifikansi 0.000 yang menunjukkan bahwa variansi data adalah tidak sama (equal variances not assumed). Hasil perbedaan LDR/LFR Bank Campuran dan Bank Asing signifikan berbeda karena terdapat perbedaan sebesar 38.70 (tingkat signifikansi $>1$ ). Rasio LDR/LFR baik yang dimiliki oleh Bank Asing dibandingkan dengan Bank Campuran masih tergolong dalam kriteria sehat dan memenuhi ketentuan regulasi yang ditetapkan, namun untuk rasio LDR/LFR Bank Campuran berada dibatas atas yang telah ditetapkan oleh pihak regulator, sehingga Bank Campuran perlu memperhatikan alternatif penghimpunan dana pihak ketiga (hasil rasio $>80 \%$ sampai dengan $<92 \%)$. Nilai rata-rata LDR/LFR Bank Asing lebih rendah menunjukkan tingginya likuiditas dan tingkat kepercayaan masyarakat kepada Bank Asing. Hal ini juga bisa dipahami karena layanan dan teknologi (e-chanel) Bank Asing lebih unggul daripada Bank Campuran. Namun Bank Campuran harus mengambil langkah strategis dalam menurunkan rasio LDR/LFR yang sangat tinggi tersebut, karena sangat berpengaruh pada tingkat likuiditas bank dan berdampak pada profil risiko bank itu sendiri.

\section{Kesimpulan Dan Saran}

Berdasarkan hasil penelitian, maka disampaikan beberapa kesimpulan sebagai berikut.

1. Perbandingan rasio CAMEL antara Bank Nasional dan Bank Pembangunan Daerah menunjukkan: dilihat dari rasio CAR, NPL, NIM Bank Pembangunan Daerah lebih unggul daripada Bank Nasional. Namun dilihat dari rasio ROA, ROE, BOPO, dan LDR/LFR Bank Nasional masih lebih unggul daripada Bank Pembangunan Daerah. Secara keseluruhan kinerja Bank Nasional lebih unggul daripada Bank Pembangunan Daerah.

2. Perbandingan rasio CAMEL antara Bank Nasional dan Bank Swasta Nasional menunjukkan: dilihat dari rasio CAR, NIM, ROA, ROE, BOPO Bank Nasional lebih unggul daripada Bank Swasta Nasional. Namun dilihat dari rasio NPL dan LDR/LFR Bank Swasta Nasional masih lebih unggul daripada Bank Nasional. Secara keseluruhan kinerja Bank Nasional lebih unggul daripada Bank Swasta Nasional.

3. Perbandingan rasio CAMEL antara Bank Campuran dan Bank Asing menunjukkan: dilihat dari rasio CAR, NPL, NIM, ROA, ROE, BOPO, maupun LDR/LFR Bank Asing masih lebih 
unggul daripada Bank Campuran. Secara keseluruhan kinerja Bank Asing lebih unggul daripada kinerja Bank Campuran.

Berdasarkan penentuan tingkat kesehatan bank menurut CAMEL dan hasil pengujian perbandingan nilai rata-rata kinerja secara umum yaitu sebagai berikut.

1. Kinerja Bank Nasional lebih unggul dibandingkan dengan Bank Pembangunan Daerah;

2. Kinerja Bank Nasional lebih unggul dibandingkan dengan Bank Swasta Nasional;

3. Kinerja Bank Asing lebih unggul dibandingkan dengan Bank Campuran.

Saran yang dapat diberikan dalam penelitian ini yaitu agar Bank wajib memelihara kondisi permodalan (CAR) tersebut agar tetap sesuai dengan ketentuan regulasi, dan menjaga tingkat kesehatan bank serta profil risiko bank, sehingga dapat lebih leluasa dalam mengembangkan aktiva produktif bank terutama aktiva produktif utama, yaitu pemberian kredit kepada nasabah dengan prinsip kehati-hatian guna menghasilkan laba bagi kepentingan investor dan pemerintah dari segi perpajakan.

Berdasarkan hasil pengujian rasio NPL dan BOPO Bank Campuran adalah yang tertinggi dibandingkan dengan Bank Nasional, Bank Pembangunan Daerah, Bank Swasta Nasional, dan Bank Asing. Manajemen Bank Campuran perlu memperhatikan dan menjaga rasio performing loan tersebut karena berdampak atas pembentukan CKPN atas Kredit Yang Diberikan. Hal tersebut juga akan berpengaruh pada rasio-rasio profitabilitas seperti ROA, ROE, BOPO. Sehingga kemampuan Bank Campuran dalam menghasilkan laba menjadi tidak maksimal yang diakibatkan pembentuan CKPN tersebut.

Berdasarkan hasil pengujian rasio LDR/LFR Bank Campuran adalah yang tertinggi dibandingkan dengan Bank Nasional, Bank Pembangunan Daerah, Bank Swasta Nasional, dan Bank Asing serta telah melewati batas atas yang telah ditetapkan oleh pihak regulator. Hal ini sangat berpengaruh pada tingkat likuiditas Bank Campuran, karena Bank Campuran juga perlu membentuk Giro Wajib Minimum (GWM) pada Bank Indonesia. Sehingga untuk memenuhi tingkat likuiditas, Bank Campuran harus melakukan borrow kepada sesama Bank yang dikenal dengan Antar Bank Pasiva dengan biaya bunga yang relatif mahal dan memperkecil NIM Bank Campuran. Bank Campuran perlu memikirkan alternatif penghimpunan dana termasuk didalamnya memperbaiki tingkat kepercayaan masyarakat kepada Bank Campuran guna memperbaharui manajemen likuiditas yang ada, agar Bank Campuran tidak lagi mengalami kesulitan likuiditas. Akibatnya, rasio NIM Bank Campuran adalah yang terendah dibandingkan dengan Bank Nasional, Bank Pembangunan Daerah, Bank Swasta Nasional, dan Bank Asing, disebabkan spread bunga yang diperoleh dan yang dibayarkan menjadi sangat kecil.

\section{Daftar Pustaka}

Al-Musai, M. A. (2014). Evaluating The Performance Of GCC Banks Using CAMEL Framework. Sintok: Universiti Utara Malaysia.

Amalia, A. (2010). Pengaruh CAR, NPL, NIM, BOPO, LDR, dan PPAP Terhadap Kinerja Rentabilitas Bank (Studi Kasus Pada Bank Devisa dan Bank Non Devisa Tahun 2004-2008). Semarang: Skripsi Fakultas Ekonomi Universitas Diponegoro.

Angel, C. G. (2014). Analisis Perbandingan Kinerja Pada Bank Nasional, Bank Campuran, dan Bank Asing yang Terdaftar di Bursa Efek Indonesia. Manado: Tesis Magister Akuntansi Universitas Sam Ratulangi.

Arianti, D. A. (2010). Pengelolaan Iklim Komunikasi Organisasi Dalam Meningkatkan Motivasi Karyawan Kantor Pusat Pemerintahan. Jakarta: Skripsi Program Studi Ilmu Komunikasi Fakultas Ilmu Sosial \& Ilmu Politik Universitas Pembangunan Nasional "Veteran".

Aswath, D. (2008). Strategic Risk Taking. Philadelphia: Wharton-Pearson Education.

Aurer, M. (2011). Basel III Handbook. Munich, German: Accenture Risk Management.

Bank Indonesia. (2008). Peraturan Bank Indonesia No. 10/15/PBI/2008 Tanggal 24 September 2008 Tentang Kewajiban Penyediaan Modal Minimum. Jakarta. 
Bank Indonesia. (2011). Surat Edaran Bank Indonesia No. 13/24/DPNP Tanggal 25 Oktober 2011 Perihal Penilaian Tingkat Kesehatan Bank Umum. Jakarta.

Bank Indonesia. (2011). Surat Edaran Bank Indonesia No. 13/30/DPNP Tanggal 16 Desember 2011 Perihal Perubahan Ketiga Atas Surat Edaran Bank Indonesia No. 3/30/DPNP Tanggal 14 Desember 2001 Perihal Laporan Keuangan Publikasi Triwulanan dan Bulanan Bank Umum serta Laporan Tertentu. Jakarta.

Bank Indonesia. (2012). Peraturan Bank Indonesia No. 14/15/PBI/2012 Tanggal 24 Oktober 2012 Tentang Penilaian Kualitas Aset Bank Umum. Jakarta.

Bank Indonesia. (2012). Peraturan Bank Indonesia No. 14/18/PBI/2012 Tanggal 28 November 2012 Tentang Kewajiban Penyediaan Modal Minimum Bank Umum. Jakarta.

Bank Indonesia. (2013). Peraturan Bank Indonesia No. 15/12/PBI/2013 Tanggal 22 November 2013 Tentang Kewajiban Penyediaan Modal Minimum Bank Umum. Jakarta.

Bank Indonesia. (2013). Peraturan Bank Indonesia No. 15/15/PBI/2013 Tanggal 24 Desember 2013 Tentang Giro Wajib Minimum Dalam Rupiah Dan Dalam Valuta Asing Bagi Bank Umum Konvensional. Jakarta.

Bank Indonesia. (2015). Peraturan Bank Indonesia No. 17/11/PBI/2015 Tanggal 24 Juni 2015 Tentang Perubahan Atas Peraturan Bank Indonesia No. 15/15/PBI/2013 Tentang Giro Wajib Minimum Bank Umum Dalam Rupiah Dan Dalam Valuta Asing Bagi Bank Umum Konvensional. Jakarta.

Bank Indonesia. (2016). Peraturan Bank Indonesia No. 18/14/PBI/2016 Tentang Perubahan Keempat Atas Peraturan Bank Indonesia Nomor 15/15/PBI/2013 Tentang Giro Wajib Minimum Bank Umum Dalam Rupiah dan Valuta Asing Bagi Bank Umum Konvensional. Jakarta.

Banks, E., \& Dunn, R. (2003). Practical Risk Management. Chichester: John Wiley \& Sons Ltd.

Basel Comittee on Banking Supervision. (2010). Basel III: A Global Regulatory Framework for More Resilient Banks and Banking Systems. Basel, Switzerland: Bank for International Settlements.

Bessis, J. (2002). Risk Management in Banking 2nd Ed. Chichester: John Wiley \& Sons Ltd.

Bradstreet, D. \&. (2007). Financial Risk Taking. New Delhi: Tata McGraw-Hill.

Budisantoso, T., \& Sigit, T. (2006). Bank dan Lembaga Keuangan Lain. Jakarta: Salemba Empat.

Christopoulos, A., Mylonakis, J., \& Diktapanidis, P. (2011). Could Lehman Brothers' Collapse Be Anticipated? An Examination Using CAMELS Rating System. Athena: International Business Research Journal.

Clorinda, K. (2013). Analisis Pengaruh Rasio Capital, Asset Quality, dan Liquidity Terhadap Kinerja Keuangan Pada Sektor Perbankan yang Terdaftar di Bursa Efek Indonesia Periode 2007-2011. Surabaya: Jurnal Ilmiah Universitas Surabaya.

Crouhy, M., Dan, G., \& Robert, M. (2001). Risk Management. New York: McGraw-Hill.

Dang, U. (2011). The Camel Rating System In Banking Supervision A Case Study. Helsinki: Arcada University of Applied Sciences International Business.

E, G. B. (2004). The New Basel Capital Accord. Phoenix: Thomson Corporation.

Esther, L. A. (2012). A Financial Performance Comparison of Foreign VS Local Banks in Ghana. Legon: International Journal of Business and Social Science.

Ferrouhi, E. M. (2014). Moroccan Banks Analysis Using CAMEL Model. Rabat: International Journal of Economics and Financial Issues Volume 4.

Fitrianto , H., \& Mawardi, W. (2006). Analis Pengaruh Kualitas Aset, Likuiditas, Rentabilitas, dan Efisiensi Terhadap Rasio Kecukupan Modal Perbankan Yang Terdaftar Di Bursa Efek Jakarta. Semarang: Universitas Diponegoro.

Galati, R. (2003). Risk Management and Capital Adequacy. New York: McGraw-Hill.

Ghasempour, S., \& Salami, M. (2016). Ranking Iranian Private Banks Based on the CAMELS Model Using the AHP Hybrid Approach and TOPSIS. Tehran: International Journal of Academic Research in Accounting, Finance and Management Sciences.

Gilbert, R., Meyer, A., \& Vaughan, M. (2000). The Role of a CAMEL Downgrade Model in Bank Surveillance. St. Louis: Federal Reserve Bank of St. Louis.

Global Association of Risk Professionals. (2005). Indonesia Certificate in Banking Risk, Workbook Level 1, Global Association of Risk Professionals. Jakarta: Badan Sertifikasi Manajemen Risiko.

Global Association of Risk Professionals. (2006). Indonesia Certificate in Banking Risk, Workbook Level 2, Global Association of Risk Professionals. Jakarta: Badan Sertifikasi Manajemen Risiko.

Global Association of Risk Proffesionals. (2007). Indonesia Certificate in Banking Risk, Workbook Level 3, Global Association of Risk Professionals. Jakarta: Badan Sertifikasi Manajemen Risiko. 
Gupta, C. R. (2014). An Analysis of Indian Public Sector Banks Using Camel Approach. New Delhi: IOSR Journal of Business and Management (IOSR-JBM).

Handayani, P. (2005). Analisa Perbandingan Kinerja Bank Dengan Rasio Keuangan. Semarang: Tesis Magister Manajemen Universitas Diponegoro.

Hutagalug, D., \& Ratnawati. (2011). Analisa Rasio Keuangan Terhadap Kinerja Bank Umum di Indonesia. Malang: Jurnal Ekonomi dan Bisnis Volume 11 Universitas Brawijaya.

Ibrahim, M. (2014). A Comparative Performance of Two Banks in United Arab. Ras Al Khaimah: Research Journal of Finance and Accounting.

Idroes, F. N. (2011). Manajemen Risiko Perbankan (Pemahaman Pendekatan 3 Pilar Kesepakatan Basel II Terkait Aplikasi Regulasi dan Pelaksanaannya di Indonesia. Jakarta: Rajawali Pers.

Indirantoro, N., \& Supomo, B. (2002). Metodologi Penelitian Bisnis Untuk Akuntansi dan Manajemen. Yogyakarta: BPFE.

Kasmir. (2012). Manajemen Perbankan. Jakarta: PT. Grafindo Persada.

Kaur, J., Kaur, M., \& Singh, S. (2015). Financial Performance Analysis Of Selected Public Sector Banks: A Camel Model Approach. Punjab: I Jaber, Vol 13 No. 6.

Kumar, M. A., Harsha, G., Anand, S., \& Dhruva, N. R. (2012). Analyzing Soundness In Indian Banking: A CAMEL Approach. Goa: Research Journal of Management Sciences.

Kuncoro, M. (2003). Metode Riset Untuk Bisnis dan Ekonomi. Jakarta: Erlangga.

Machfoedz , I. (2006). Metodologi Penelitian. Yogyakarta: Fitrimajaya.

Malik, K. (2007). Good Corporate Governance. Yogyakarta: Kreasi Total Media.

Mili, M., Sahut, J.-M., \& Trimche, H. (2014). Determinants of the Capital Adquacy Ratio of Foreign Bank's Subsidiaries: The Role of the Interbank Market Regulation of Multinational Banks. Paris: IPAG Busniness School Working Paper Series.

Misra, S., \& Aspal, P. (2013). A Camel Model Analysis of State Bank Group. Jalandhar: World Journal of Social Sciences.

Mohiuddin, G. (2014). Use of CAMEL Model: A Study on Financial Perfomance of Selected Commercial Banks in Bangladesh. Chittagong: Universal Journal of Accounting and Finance.

Nurazi, R., \& Evans, M. (2005). An Indonesian Study of The Use of CAMEL(S) Ratios as Predictors of Bank Failure. Lismore: Journal of Economic and Social Policy.

Ochei, A. I. (2013). Capital Adequacy, Management and Performance In The Nigerian Commercial Bank (1986-2006). Ogun State: African Journal of Business Management.

Otoritas Jasa Keuangan. (2016). Peraturan Otoritas Jasa Keuangan No. 04/POJK.03/2016 Tanggal 26 Januari 2016 Tentang Penilaian Tingkat Kesehatan Bank Umum. Jakarta.

Otoritas Jasa Keuangan. (2016). Peraturan Otoritas Jasa Keuangan No. 11/POJK.03/2016 Tanggal 29 Januari 2016 Perihal Kewajiban Penyediaan Modal Minimum. Jakarta.

Otoritas Jasa Keuangan. (2016). Peraturan Otoritas Jasa Keuangan No. 18/POJK.03/2016 Tanggal 16 Maret 2016 Tentang Penerapan Manajemen Risiko Bagi Bank Umum. Jakarta.

Otoritas Jasa Keuangan. (2016). Peraturan Otoritas Jasa Keuangan No. 32/POJK.03/2016 Tanggal 08 Agustus 2016 Tentang Perubahan Atas Peraturan Otoritas Jasa Keuangan No. 06/POJK.03/2015 Tentang Transparansi dan Publikasi Laporan Keuangan Bank. Jakarta.

Otoritas Jasa Keuangan. (2016). Peraturan Otoritas Jasa Keuangan No. 34/POJK.03/2016 Tanggal 22 September 2016 Tentang Perubahan Atas Peraturan Otoritas Jasa Keuangan No. 11/POJK.03/2016 Tentang Kewajiban Penyediaan Modal Minimum. Jakarta.

Otoritas Jasa Keuangan. (2016). Peraturan Otoritas Jasa Keuangan No. 6/POJK.03/2016 Tanggal 27 Januari 2016 Tentang Kegiatan Usaha dan Jaringan Kantor Berdasarkan Modal Inti Bank. Jakarta.

Otoritas Jasa Keuangan. (2016). Surat Edaran Otoritas Jasa Keuangan No. 14/SEOJK.03/2016 Tanggal 29 April 2016 Tentang Pembukaan Jaringan Kantor Berdasarkan Modal Inti. Jakarta.

Otoritas Jasa Keuangan. (2016). Surat Edaran Otoritas Jasa Keuangan No. 24/SOJK.03/2016 Tanggal 14 Juli 2016 Tentang Pedoman Perhitungan Aset Tertimbang Menurut Risiko Untuk Risiko Operasional Dengan Menggunakan Pendekatan Indikator Dasar (PID). Jakarta.

Otoritas Jasa Keuangan. (2016). Surat Edaran Otoritas Jasa Keuangan No. 38/SEOJK.03/2016 Tanggal 08 September 2016 Tentang Penggunaan Metode Standar Dalam Perhitungan Kewajiban Penyediaan Modal Minimum Bank Umum Dengan Memperhitungkan Risiko Pasar. Jakarta. 
Otoritas Jasa Keuangan. (2016). Surat Edaran Otoritas Jasa Keuangan No. 42/SEOJK.03/2016 Tanggal 28 September 2016 Tentang Pedoman Perhitungan Aset Tertimbang Menurut Risiko untuk Risiko Kredit dengan Menggunakan Pendekatan Standar. Jakarta.

Pastory, D., \& Mutaju, M. (2013). The Influence of Capital Adequacy on Asset Quality Position of Banks in Tanzania. Dalian: International Journal of Economic and Finance.

Presiden Republik Indonesia. (1998). Undang-Undang nomor 10 Tahun 1998 Tentang Perbankan. Jakarta.

Rumondor, R. (2013). Perbandingan Kinerja Keuangan Bank Mandiri, BNI, dan BRI Yang Terdaftar di Bursa Efek Indonesia. Manado: Universitas Sam Ratulangi.

Salhuteru, F., \& Wattimena, F. (2015). Bank Performance With CAMELS Ratios Towards Earnings Management Practices In State Banks and Private Banks. London: Advances In Social Sciences Research Journal.

Sandhya, C. V. (2014). Camel Framework in Banks - Indian Scenario. Bangalore: Indian Journal of Applied Research.

Solomon, J. (2010). Corporate Governance and Accountability 3rd Edition. Chichester, West Sussex, United Kingdom: John Wiley \& Sons Ltd.

Suba, N., \& Jogi, K. (2015). Evaluating Performance of Private Sector Banks HDFC \& ICICI: An Application of Camel Model with Capital \& Earning Parameter. Gujarat: Research Hub International Multidisciplinary Research Journal (RHIMRJ) Volume 2.

Sugiarti, W. (2012). Analisis Kinerja Keuangan Dan Prediksi Tingkat Kesehatan Bank Dengan Menggunakan Metode CAMEL Pada Bank Umum Yang Tercatat Di Bursa Efek Indonesia. Depok: Jurnal Akuntansi Fakultas Ekonomi Universitas Gunadarma.

Sugiyono. (2008). Metode Penelitian Kualitatif, Kuantitatif, dan Research \& Development $(R \& D)$. Bandung: Alfabeta.

Sukardi. (2009). Metodologi Penelitian Pendidikan. Yogyakarta: Bumi Aksara.

Sumani. (2013). Analisis Penilaian Tingkat Kesehatan Bank Dengan Metode CAMELS Pada Bank Syariah Mandiri Tahun 2006 - 2010. Jember: Jurnal Orasi Volume 7 No. 1.

Sunggono, B. (2005). Pengantar Hukum Perbankan. Jakarta: CV. Mandar Maju.

Suyatno, T. (2007). Kelembagaan Perbankan. Jakarta: PT. Gramedia Pustaka Utama Edisi Ketiga.

Utomo, P. (2008). Pengaruh Non Performing Loan Terhadap Kinerja Keuangan Bank Berdasarkan Rasio Likuiditas, Solvabilitas, dan Profitabilitas Pada PT. Bank Mandiri (Persero), TBK. Jakarta: Tesis Universitas Gunadarma.

Widati, L. W. (2012). Analisis Pengaruh CAMEL Terhadap Kinerja Perusahaan Perbankan Yang Go Publik. Semarang: Dinamika Akuntansi, Keuangan, dan Perbankan.

Widjanarto. (2005). Hukum Dan Ketentuan Perbankan Di Indonesia. Jakarta: Grafiti.

Widyanto, E. A. (2012). Analsis Tingkat Kesehatan Dan Kinerja Keuangan Bank Dengan Menggunakan Metode CAMEL (Studi Kasus Pada PT. Bank Mega Syariah Indonesia periode 2008 - 2010). Samarinda: Jurnal Eksis Volume 8 No. 2.

Yanti, L. P., Suwendra, I., \& Susila, G. (2014). Analisis Tingkat Kesehatan Bank Dengan Menggunakan Metode CAMEL. Singraja: e-Journal Bisma Universitas Pendidikan Ganesha Jurusan Manajemen.

Yulianto, A., \& Sulistyowati, W. (2012). Analisis CAMELS Dalam Memprediksi Tingkat Kesehatan Bank Yang Terdaftar Di Bursa Efek Indonesia Periode 2009 - 2011. Jakarta: Jurnal Media Ekonomi \& Teknologi Informasi 